\title{
Investigation to Improve the Process of Pre-service Teachers' Reflective Thinking Skills through an Action Research
}

\author{
Ufuk Töman \\ Faculty of Education, Bayburt University, Turkey
}

Copyright $(\mathrm{C} 2017$ by authors, all rights reserved. Authors agree that this article remains permanently open access under the terms of the Creative Commons Attribution License 4.0 International License

\begin{abstract}
This study aimed to pre-service teachers' reflective thinking and to reveal development of reflective thinking during the process of teaching and learning. This study was designed in the form of action research due to the nature of the case examined. The participants were 4 pre-service teachers at Bayburt University Faculty of Education Department of Elementary Science Education. Video recordings and reflective journals were used to collect the data for study. The qualitative data obtained were analyzed using the content analysis method. Reflective thinking skills developed at the end of the training process of pre-service teachers. However, the work of reflective thinking, planning a course for pre-service teachers participating in this study was shown to contribute to the professional development for the implementation and evaluation. The work done to improve the process of reflective thinking of pre-service teachers is determined to have a level reflecting the start of the technical field. At later stages of the process pre-service teacher are determined level of application and critical reflection levels. In this context, experience of pre-service teachers and reflection on these experiences provide that reflective thinking skills development for the planning, implementation and evaluation of a lesson.
\end{abstract}

Keywords Reflective Thinking, Reflective Thinking Levels, Pre-service Teachers, Reflective Journals

\section{Introduction}

Reflective thinking helps shape the weaknesses and strengths of human behavior. [1]. However, learning reflective thinking effectively and making benefit of these skills effectively cannot be realized automatically. In this context educational institutions have an important role to supply individuals with the reflective thinking skills and to develop them [2, 3]. In reflective thinking students are capable of determining learning deficiencies and become liable for their learning. In the learning environments where it is aimed that students should become skillful at reflective thinking teachers must have reflective thinking skills and use their skills in learning environment [4, 5, 6]. Teachers colleges have significant roles in bringing teachers in reflective thinking skills [7, 8]. To develop reflective thinking skills in pre-service teachers is considered as a solution by educators in enhancing educational quality [9]. As in student-centered approaches changing roles of student and teacher has also caused changing instruction schedules.

Pre-service teachers have an important place in developing reflective thinking by taking the time to get used to diary. As, by reflective diaries, pre-service teachers are able to make reflection pre-eminently by establishing more signifying relations between theory and practice regarding their own learning processes $[10,11]$. In this study the primary aim for the pre-service teachers to use reflective diaries in learning surroundings is to add awareness to them about what they do, how they do, why they do as well as what they do in different fields. On the other hand, to give pre-service teachers a back about developing their skill for solving problems. In this way, pre-service teachers would realize their weak and strong sides they own in the theoretical knowledge and practice fields.

Although there are different models about reflective thinking that has been put forward up to today the common ground of them is the reflection degrees. In this study "conscious rationalism" model which is identified by Van Manen [12] is used while reflection levels of the pre-service teachers are determined. As this is one of the most referred models in the literary related to reflective thinking $[13,14$, $15,16,17,18,19,9]$. The most important feature of the reflection model introduced by Van Manen [12] is to reveal reflection levels clearly and lucidly [20]. The model presented by Van Manen [12] consists mainly of reflection levels in technical, practice and critical scopes. Reflection 
level in technical scope is the tool used by pre-service teachers who are in lack of skill or experience for changing theoretical knowledge into practice [9]. These pre-service teachers lay emphasis on sufficiency and efficiency of the measurable results in class. The pre-service teachers who make reflection in technical scope simply explain their observations. On the other hand, they evaluate problem solutions in only existing application dimension [19]. Reflection in application scope can be described as the reflection scope in which teachers or pre-service teachers start up making use of experiences regarding their teaching skills, thinking on problems they face and trying to find way outs [19]. In this scope pre-service teacher or teacher analyses student behaviors to find out if they achieve the aim or not, how they achieve the aim or why they fail to achieve the aim. They interpret the observable student behaviors on the basis of their individual perceptions [21]. Reflection in critical scope is the latest and the highest level of reflection. In the reflection in critical scope relation between teaching practices and ethical values is probed. Teachers or pre-service teachers' pay regard to the value of these aims in achieving aims. A basis is provided when reflection is made in critical scope on which main values and social situations such as education, equality, attention and justice are placed [17].

In this research reflective diaries are used for the pre-service teachers in order to provide them an opportunity to review their teaching programs, teaching approaches, teaching methods and techniques, teaching materials and assessment methods. In this way pre-service teachers may evaluate reflective journals to prepare a better teaching environment and improve their teaching skills.

\section{Method}

This research that is made for developing reflective thinking skills of pre-service teachers along teaching process is designed as an action research due to the characteristic of the case that is examined. Action research is described in literature in very different forms. Action research is a systematic research process that is made by teachers who are researchers in the same time in educational surrounding to find out how students can learn in the best way, how they educate and how schools process [22].

Action research whose mainstay is to solve problems has recently become a method applied by the pre-service teachers, teachers and researchers intended for removing rupture between theory and practice. The aim of this method is to solve a special problem in school environment or to develop a special application [23, 24]. Concordantly, Şencan [25] specifies that action research is a method of research made for a limited number of persons, departments or institutions. Şencan compares action research with case research and expresses that the most significant difference between them is the researcher's role in the process. Because the role of researcher is only an observer or evaluative in case studies in the action research he or she personally applies the change or intervention. Action research is a process that starts up with a problem situation. It must be planned regularly before data collection and it comprises flexibility in data collection, analysis and reporting and necessitates regular observations [26, 27, 28].

\subsection{Participants in the Research}

Participants of the research are instructors who are charged with Bayburt University Education Faculty Department of Elementary Science Teaching and four pre-service science teachers. Reflective diaries are used to collect data in the research. The reason for choosing research group 4 people teacher candidates is in-depth processes of reflective thinking. Action research does not aim at the generalization. The important thing is the development processes of reflective thinking skills in a clear manner. General characteristics of the pre-service teachers who are participating in the research are given in the Table 1.

Table 1. General Characteristics of the Pre-service Teachers who are participating the Research

\begin{tabular}{|c|c|}
\hline Gender & 4 Pre-service Teacher who are Participating in the Research \\
\hline Woman & ÖA-4, ÖA-24 \\
\hline Man & ÖA-12, ÖA-30 \\
\hline Total & 4 \\
\hline
\end{tabular}

\subsection{Data Collection}

Applications that are performed by the pre-service teachers in the classes of Special Teaching Methods I and Special Teaching Methods II were videotaped and they were given to them after each application. Pre-service teachers filled up the reflective diaries after each application. Some questions in reflective diaries were given to the pre-service teachers as being a guidance and they were requested to fill up their diaries in direction of these questions. In preparing these questions benefit of the studies made by Dolapçıŏlu [4], Ekiz [29], Köksal and Demirel [30], Yorulmaz [31] and Şahin [16].

The research consists of two sections: special teaching methods I class that handles the theoretical teaching and practices in 2015-2016 spring period and special teaching methods II class that handles the principle practices towards reflective thinking in 2016-2017 fall term.

Special Teaching Methods I class is an important class in training teachers with two hour theory and 2 hours practice in every week and consists a term of 14 weeks along the period. The class was given by the researcher in the first 10 weeks (40 hours) of 14 weeks in direction of theoretical teaching. In the last four weeks of the period pre-service teachers were given subjects different from science class teaching program and every pre-service teacher was requested to make a class plan of 20-25 minutes and to teach. Classes of every pre-service teacher were videotaped. On the other hand, the pre-service teachers were requested to keep a reflective diary by following up the class that was 
videotaped in the end of practice.

Special Teaching Methods II class in the fall term of 2016-2017 school year which is the second section of the research consists totally 14 weeks (56 hours) along the period two hours for theory and two hours for practice. Researcher gave different subjects to the pre-service teachers in science class teaching program and requested that each pre-service teacher performed teaching individually for two times in the period. The pre-service teachers kept reflective diaries by analyzing classes videotaped in the end of each practice.

\subsection{Data Analysis and Interpretation}

The data gained by reflective diaries is analyzed integrally. For this content, analysis is made and data analysis techniques $[32,24]$ are used. Yıldırım and Şimşek [24] explained content analysis and data analysis techniques in four steps as 'data codifying, making theming, organizing data according to codes and themes and interpretation of findings'. Before collecting data a code list is made by paying regard to theory and conceptual framework which underlying the research in first type. When there is no conceptual structure to help analyze the data the secondary type is applied and codes are brought about by completely looking at data. The third one is a codification type which is brought about by the combination of the first two codifying types. While a predetermined code list is directing the content analysis the new codes that are revealed in the wake of inductive approach is added to the predetermined code list or the former codes are put in the place of new ones. In this research codifying is performed within the general framework. The criteria for investigating data within the theoretical framework of the research are determined before data is evaluated. Consequently, codes that are revealed in the scope of framework from each case are examined. After the codifying data is organized and interpreted.

How a path is followed in the practice of pre-service teachers is explained by theoretical or conceptual information by making bindings among the themes that appeared about science pre-service teachers. In this research it is given place to crucial samples that are taken from the documents unchanging belong to the reflective diaries in order to illuminate the cases that are revealed by the researcher. Some abbreviations are used in the sample when indicating pre-service teachers and reflecting spots. Expansions of these abbreviations are as follow. For example, ÖA-1 signifies 'the first student from the science pre-service teachers'.

ÖA: Science pre-service teacher. 1: First pre-service teacher, 2: Second pre-service teacher, 3: Third pre-service teacher, 4: Fourth pre-service teacher, T: Reflecting in technical level, U: Reflecting in application level, E: Reflecting in critical level.

\subsection{Validness and Reliability of the Research}

Validness in an action research means to collect data in a way to create a correct Picture down to the last detail by making observations. On the other hand, reliability means to have an experience a process to be counted on or an experience of data collecting and analyzing them. Validness in an action research is provided by criteria of plausibility, transferability, reliability and verifiability [22]. Because the data collected in an action research is typical and local.

According to Mills [22] plausibility in an research can be increased by staying in research surrounding for long period of time and achieving data satisfaction, making insistent observations, gaining the registered data and supporting the research with sufficient resources [23]. Another criterion that is paying regard to providing validness of an action research is "transferability". In order to supply transferability in this research

- Research time is described in details.

- It is tried to collect descriptive data in the process of research.

- It is tried to be impartial as soon as possible in descriptions.

- It is tried to present the results gained from data as a whole by associating them to each other and literature.

The criterion of verifiability is to collect data in the time of research impartially and objectively [28; 22]. In order to provide the criterion of verifiability of this research

- It is tried to collect data in the process of research by using video recordings.

- Video recordings are monitored together with the pre-service teachers and it is paid regard to their reviews and suggestions about data collecting tools and data collecting process.

The researcher tried to realize the following practices in regard with the reliability of the research:

- Direct views of the participants are quoted in interpretation of data.

- Pre-service teachers certified the data after they have been put on paper.

- In analyzing data another expert monitored certain video and tape recordings for the determined categories.

\section{Findings}

In this section findings gained from data analysis collected from reflective diaries regarding developing reflective thinking skills of science pre-service teachers in regard with class planning, practice and evaluations in three different practices are presented.

\subsection{Findings Gained from the Reflective Diaries of Pre-service Teachers towards Planning of Teaching Process}

The findings that are revealed by analyzing the data procured from the reflective diaries of the pre-service teachers towards planning of teaching process are as follow. The findings that are obtained are discussed by paying 
regard to the relative literature.

The findings obtained by the diaries in regard with the teaching process planning of the pre-service teacher are examined, as it is seen in Table 2, reflection in technical space in the first practice of all pre-service teachers' reflection is determined. When the statements of pre-service teachers are examined it is seen that they generally make statements about the targets if they are effective or not. A pre-service woman teacher with code of ÖA-4 says "the targets I specified were effective" as an answer to a question related to teaching process planning in the framework of reflection level in technical space. This pre-service teacher specified that her targets were effective but fell short of making explanations about the questions of "why" and "how". In the second practices of the pre-service teachers it is determined that they except for the pre-service teachers with ÖA-12 code make proper statements about reflection level in the practice space in regard with teaching process planning. Reflection in technical space is revealed in the pre-service teacher with ÖA-12 Code. The woman pre-service teacher with ÖA-24 Code says in regard with the reflection level in practice space that "I do not think that my targets are properly effective. I cannot say that the samples given from the daily life is placed in every student's life. As there is a possibility about students that they are being in every part of our country I should have paid regard to the targets as there are not dams, springs, and lakes as an sample of natural surroundings in every city. That is to say it would have been better if the targets addressing population living in big city and small city were picked up. There are substantial differences among the big city, small city and natural surroundings. It should have been given samples proper to students. However, I think that I was not able to present proper samples." The pre-service teacher mentioned that her targets are not effective. She also talked about her failing to reach effectiveness on the basis of her subjective interpretation. When the third practices of the pre-service teachers are examined reflection level is revealed in all of them. The male pre-service teacher with ÖA-30 code said about the reflection level in critical space "I had 4 targets. I gave my targets effectively. Because they are on current issues and I picked up targets remembered easily. The samples should be interesting and being in life for the students in order to clarify the subject and to be remembered easily. In this way class would be both unjoyful and lasting. Classes should be planned in this way." When the statements of the pre-service teacher who reveals reflection in the critical space it is dedicated that he made inferences in regard with the educational contribution of the targets that are specified in the reflective diary. Making reflections in the critical space by the pre-service teachers indicates that they pay regard to the previous practices when they are planning classes [14].

Table 2. The findings obtained from the diaries of pre-service teachers in regard with planning of teaching process

\begin{tabular}{|c|c|c|c|c|c|c|c|c|c|c|c|}
\hline \multirow{2}{*}{$\begin{array}{l}\text { Teaching } \\
\text { Process }\end{array}$} & \multirow{2}{*}{ Questions } & \multirow{2}{*}{$\begin{array}{l}\text { Pre-service } \\
\text { Teacher }\end{array}$} & \multicolumn{3}{|c|}{$\begin{array}{l}\text { Reflection Levels } \\
\text { (I. Application) }\end{array}$} & \multicolumn{3}{|c|}{$\begin{array}{l}\text { Reflection Levels } \\
\text { (II. Application) }\end{array}$} & \multicolumn{3}{|c|}{$\begin{array}{l}\text { Reflection Levels } \\
\text { (III. Application) }\end{array}$} \\
\hline & & & $\mathrm{T}$ & U & $\mathrm{E}$ & $\mathrm{T}$ & $\mathrm{U}$ & E & $\mathrm{T}$ & U & E \\
\hline \multirow{16}{*}{ Planning } & \multirow{4}{*}{$\begin{array}{l}\text { Are the targets I } \\
\text { specified effective? } \\
\text { /Why? If not why } \\
\text { there are not } \\
\text { effective? }\end{array}$} & ÖA-4 & $\checkmark$ & & & & $\checkmark$ & & & & $\checkmark$ \\
\hline & & ÖA-12 & $\checkmark$ & & & $\checkmark$ & & & & & $\checkmark$ \\
\hline & & ÖA-24 & $\checkmark$ & & & & $\checkmark$ & & & & $\checkmark$ \\
\hline & & ÖA-30 & $\checkmark$ & & & & $\checkmark$ & & & & $\checkmark$ \\
\hline & \multirow{4}{*}{$\begin{array}{l}\text { Could I make subject } \\
\text { content } \\
\text { properly?/Why?/If } \\
\text { not, which changes I } \\
\text { supposed to make in } \\
\text { the arrangement?/ } \\
\text { Why? }\end{array}$} & ÖA-4 & $\checkmark$ & & & & $\checkmark$ & & & & $\checkmark$ \\
\hline & & ÖA-12 & $\checkmark$ & & & $\checkmark$ & & & & $\checkmark$ & \\
\hline & & ÖA-24 & $\checkmark$ & & & & $\checkmark$ & & & & $\checkmark$ \\
\hline & & ÖA-30 & $\checkmark$ & & & $\checkmark$ & & & & $\checkmark$ & \\
\hline & \multirow{4}{*}{$\begin{array}{l}\text { Which is the most } \\
\text { important problem I } \\
\text { experienced in the } \\
\text { process of subject } \\
\text { planning? Why? }\end{array}$} & ÖA-4 & $\checkmark$ & & & & $\checkmark$ & & & $\checkmark$ & \\
\hline & & ÖA-12 & $\checkmark$ & & & & $\checkmark$ & & & & $\checkmark$ \\
\hline & & ÖA-24 & $\checkmark$ & & & & & $\checkmark$ & & & $\checkmark$ \\
\hline & & ÖA-30 & $\checkmark$ & & & & $\checkmark$ & & & & $\checkmark$ \\
\hline & \multirow{4}{*}{$\begin{array}{l}\text { To what would I pay } \\
\text { regard when I make } \\
\text { arrangement and what } \\
\text { would I change If I } \\
\text { had an opportunity to } \\
\text { do it again? Why? }\end{array}$} & ÖA-4 & $\checkmark$ & & & & $\checkmark$ & & $\checkmark$ & & \\
\hline & & ÖA-12 & $\checkmark$ & & & $\checkmark$ & & & & $\checkmark$ & \\
\hline & & ÖA-24 & $\checkmark$ & & & & $\checkmark$ & & & & $\checkmark$ \\
\hline & & ÖA-30 & $\checkmark$ & & & & $\checkmark$ & & & & $\checkmark$ \\
\hline
\end{tabular}


When the findings are examined that are obtained from the diaries of pre-service teachers about arrangement of subject contents it is seen that all of pre-service teachers found the arrangement of subject contents were proper. As it is seen in Table 2, reflection in technical space is determined in the first practice of all pre-service teachers. As an example the pre-service teacher with ÖA-4 code made statements as "My acquisitions were according to the subject arrangement, but I told them speedily." When the second practice of the pre-service teachers is examined it is seen that the pre-service teachers with ÖA-12 and ÖA- 30 codes own the reflection level in technical space. The pre-service teacher with ÖA-24 code made statements in such way of "The meaning of the surrounding is living of living and non-living things together. For this reason, it was necessary that primarily I should have told the living and non-living things and then made and entrance in regard with living and non-living things. Therefore, I made an entrance to the living and non-living things. My subject arrangement was proper. I have managed more effective and understandable exposition." The pre-service teacher with ÖA-24 code who makes reflection in the practice space did not make statement about how the subject arrangement is made. On the other hand, he interpreted the points he paid regard to when he is making subject arrangement. When the third practice of the pre-service teachers is examined it is seen that the pre-service teachers with ÖA-12 and ÖA-30 codes own reflection level in the practice space. On the other hand, the pre-service teachers with ÖA-4 and ÖA-24 codes own the reflection level in the critical space. The pre-service teacher with ÖA-24 code said about the reflection in critical space: "I managed to make subject content arrangement properly. Because I realized my targets from specific to general. I made the arrangement I planned by paying regard to the concepts in the subject. I took care of averting subject and concept rupture. In the exposition of subject, the disengaged concepts can be changed into ambiguity. Concepts should be in meaningful relations in order to clarify the subject. In this way understanding the subject can be easy." It is found out that the pre-service teacher who makes reflection in critical space interrogated the relation between subject arrangement and practice and made planning for the future Professional practices. This finding is in accord with the results in the study of Evans [38] and Ekiz [29].

When the findings obtained from the diaries in regard with the most important problem experienced in teaching process planning are examined, it is found out that the pre-service teachers have the problems in all practices in terms of attainment selection, planning teaching methods. Reflection level in the technical space is determined in the first practice of all pre-service teachers. The pre-service teacher with ÖA-4 code answered the question in regard with the most important problem that is experienced in the planning process of the practice in such way: "I had 12 attainments. I had a difficulty when I picked up the attainment." This is an answer that is accordance with the reflection level in the technical space. When the statements of the pre-service teacher are examined it is seen that he did not touch on the things to which he paid regard and "why" he had difficulties in what points. In the second practice the pre-service teachers except for with ÖA-24 code used proper statements about the problems they faced. The pre-service teacher with ÖA-30 code revealed reflection in the critical space. As an example of reflection level in practice space the pre-service teacher with ÖA-30 code said that "I believe that I made subject arrangement when I making planning. There was easy-difficult relation in the subject arrangement. I arranged the subject from easy to difficult. The most serious problem for me is the one related to material. As my subject is current and I am not able to materialize I did not find material. Only dirty and clean water came into my mind. Because I thought that I was able to reinforce the remain with exposition and at the same time I looked for material but I did not find". The pre-service teacher who made reflection in practice space identified only the reasons of the problems he experienced in the class planning and specified what have to be done to be averted problems. When the third practice of the pre-service teachers is examined it is understood that the pre-service teachers except for the one with ÖA-4 code own reflection level in the critical space. In the pre-service teacher with ÖA-4 code reflection in the practice space is revealed. The pre-service woman teacher with ÖA-24 code spoke about the reflection level in the critical space in this way "Interesting events supporting the subject, pictures, actions in the class, daily samples are the good tools and equipment that are used to enforce and to understand the subject. After planning the subject I looked for the interesting events related to the subjects. I found some interesting events but I failed in some subjects. I investigated interested information to enhance the curiosity of students. Interested happenings told by my teachers have always moved me in my educational life. In this way students participated in the class with special excitement and always been willing. $\mathrm{He}$ wonders what my teacher will be telling us. Even students come to the class after making some researches. Class become more enjoyable. I requested the students to do something after giving them subjects. I have always wanted to give student-centered class not teacher-centered. I seemed to motivate them for research. Students learn better when they are active, to tell the class on the board. I think that teachers have to give this right to the students. Such planning is a must for the student-centered exposition." When the statements of the pre-service teacher who makes reflection in the critical space are examined we can say that the pre-service teacher dealt with the educational value in relation with the problems and made generalizable judgements.

The pre-service teachers concentrated the points such as applying the plan without being changed, placing review in the plan and using time effectively when they are asked 
what will they pay regard to if they have opportunity to plan teaching process again. All of the pre-service teachers gave answers in accordance with the reflection level in the technical space. A pre-service teacher with ÖA-4 code answered the question about the reflection level in the technical space as follow: "I would have used the same methods. Because I think that they (methods) are effective". When the statement of the pre-service teacher is examined it is seen that he mentioned about the methods as effective but he did not mention which methods are effective and in what terms they are effective. The pre-service teachers answered the question about what should they pay regard to in case they plan teaching process again in the second practice in accordance with the reflection level in technical space except for the one with ÖA-12 code. He used the statements in accordance with the reflection in technical space. The pre-service teacher with ÖA-30 code answered the question about the reflection in practice space as "I would have made a method selection attentively by making a wide-ranging research and examined all methods. I would not have allowed for station method which is one of my method and technique. Because I do not think that station method is able to provide an effective learning. Students write about things that are not related to the subject. I grew aware that they are bored and have difficulties. I would have planned jigsaw method instead of station method that is more lasting, effective. On the other hand, jigsaw method provides an opportunity for the students to be able to interact with each other and work concertedly." The pre-service teacher who makes reflection in practice space has not only made definitional statements in regard with the teaching methods that are used. As well as he interpreted what can be done differently related with planning by setting out from the definitional statements based on his subjective perceptions. When the third practice of the pre-service teachers is examined it was specified that they own reflection level in critical space except for the ones with ÖA-4 and ÖA-12 codes. As an example of reflection in critical space the pre-service teacher with ÖA-30 code said: I acted easily when I made planning time. As the expositions are student-centered I wanted students whatever act as they wish. I have never missed any students who make researches and endeavors. I allowed them to make presentation on the board not to waste their efforts. Class enjoyed this presentation. I have not wasted extra time as I wanted to do so. If I had opportunity to do that again I would have adjusted time, however I taught a lesson for 50 minutes along without boring. I have got positive reactions from the class. In this practice I only lead the way and students have done it. Students thought everything and they made al researches. I thought that the lesson was enjoyable when it was taught in that way. For the first time I taught lesson without looking at my watch. Teachers have to take the students in the center and use educational methods to increase students' self-confidences. In daily life a teacher has to adjust time very well. He or she should leave the subject in a place that student would be curious about next class. At the same time, he or she should not forget what he or she taught in the previous class. In this way the subject becomes integral and the rate of being forgotten is reduced." The pre-service teacher who owns reflection level in the critical level made inferences towards teaching skills that are necessary to realize interclass activities providing student participation.

\subsection{Findings Obtained from the Reflective Diaries towards Practices of Teaching Activities of Pre-service Teachers}

The data obtained from the reflective diaries towards practice of teaching activities of pre-service teachers is analyzed profoundly. The findings are as follow. The findings obtained are discussed by paying regard to the relative literature.

When the findings obtained from the reflective diaries of pre-service teachers towards practice of teaching activities are examined all of the first practices of the pre-service teachers in the technical space are revealed as it is shown in Table 3. The pre-service woman teacher with ÖA-4 code answered the questions toward practice of teaching-learning activities "The methods I used were effective? Why? If it is not which methods can be effective/Why? As I think that the methods I used in relation with the subject were effective. However, the pre-service teacher did not mention which methods she used and she did not make sufficient explanations about in what terms the methods are effective. The pre-service teachers predominantly used statements in relation with the used teaching methods in second practices in accordance with the reflection level in practice space. Only the pre-service teacher with ÖA-12 code answered to the question towards reflection level in critical space. The preservice teacher with ÖA-4 code said about the reflection level in practice space "Question and answer method was effective. Because before I explained the subject I controlled readiness and the rudiments of the students. I gave chance to all of them in order to motivate them to think about the subject. I used this method in certain sections of the class. Another method I used was demonstration method which was effective. I indicated the concept of power by materializing it. Because I tried to make learning more lasting and more effective. However, I should have supported it by different and visual materials. As materials are striking and they are memorable in terms of learning." A pre-service teacher with ÖA-4 code who makes reflection on practice space analyzed the student behavior in order to find out how the teaching methods have become effective and if they not why they have not been effective. In the third practice of the pre-service teachers it is well seen in Table 3 that they have made reflections in the practice and critical spaces. The pre-service teacher with ÖA-30 code said about the reflection in the critical space: "I 
called everyone who comes to the blackboard in order to bring about heterogeneous groups. I determined two students as hardworking a one student as non-hardworking while I was bringing about the heterogeneous groups. It is very important to teach a subject together with the heterogeneous groups. The aim in the group activities is to find out his or her socializing degree, strengthening his or her interaction, and understanding his or her self-confidence situation. The more effective teaching can be made by the interaction of the unsuccessful students in the class with successful students. It is certain in terms of scientific view that unsuccessful students become successful when they interact with heterogeneous groups. Even if student is not willing, he or she forces himself or herself to work hard and grows awareness about her or his responsibilities in order not to feel embarrassed. I used question and answer method effectively. This method strengthens interaction and increases his or her self-confidence as well as it equips the student with the skill of speaking before audience. In every title, I measured up prior knowledge of the students by posing questions to them and commentated the subject. The question answer method is helpful for me determining how I will commentate the subject and measure up the knowledge of students. When I used the question answer method I wanted students to raise hand. It was necessary for me to hear every view without interrupting them. Students should be heard even if their views are wrong and they need be considered. In this way students become active in the class. If we are angry with the students who say wrong things his or her self-confidence would be decreased and we will lose them." When the statements of the pre-service teacher with ÖA-30 code are examined, it is seen that he deals with the educational values of the teaching methods and develops original thoughts towards teaching methods. This situation resembles the studies that have been already made $[29,16,37,9]$.

Table 3. The findings obtained from the diaries towards teaching activities practice of the pre-service teachers

\begin{tabular}{|c|c|c|c|c|c|c|c|c|c|c|c|}
\hline \multirow{2}{*}{$\begin{array}{c}\text { Teaching } \\
\text { Process }\end{array}$} & \multirow{2}{*}{ Questions } & \multirow{2}{*}{$\begin{array}{l}\text { Pre-service } \\
\text { Teacher }\end{array}$} & \multicolumn{3}{|c|}{$\begin{array}{l}\text { Reflection Levels } \\
\text { (I. Practice) }\end{array}$} & \multicolumn{3}{|c|}{$\begin{array}{l}\text { Reflection Levels } \\
\text { (II. Practice) }\end{array}$} & \multicolumn{3}{|c|}{$\begin{array}{l}\text { Reflection Levels } \\
\text { (III. Practice) }\end{array}$} \\
\hline & & & $\mathrm{T}$ & $\mathrm{U}$ & E & $\mathrm{T}$ & $\mathrm{U}$ & E & $\mathrm{T}$ & $\mathrm{U}$ & $\mathrm{E}$ \\
\hline \multirow{16}{*}{ Practice } & \multirow{4}{*}{$\begin{array}{l}\text { Are Methods I use } \\
\text { effective? Why? If it } \\
\text { is not which } \\
\text { methods can be } \\
\text { effective? Why? }\end{array}$} & ÖA-4 & $\checkmark$ & & & & $\checkmark$ & & & $\checkmark$ & \\
\hline & & ÖA-12 & $\checkmark$ & & & & & $\checkmark$ & & $\checkmark$ & \\
\hline & & ÖA-24 & $\checkmark$ & & & & $\checkmark$ & & & & $\checkmark$ \\
\hline & & ÖA-30 & $\checkmark$ & & & & $\checkmark$ & & & & $\checkmark$ \\
\hline & \multirow{4}{*}{$\begin{array}{l}\text { Are methods I used } \\
\text { effective? / Why? If } \\
\text { it is not which } \\
\text { materials can be } \\
\text { more effective? }\end{array}$} & ÖA-4 & $\checkmark$ & & & & $\checkmark$ & & & & $\checkmark$ \\
\hline & & ÖA-12 & $\checkmark$ & & & $\checkmark$ & & & & $\checkmark$ & \\
\hline & & ÖA-24 & $\checkmark$ & & & & $\checkmark$ & & & $\checkmark$ & \\
\hline & & ÖA-30 & $\checkmark$ & & & & $\checkmark$ & & & $\checkmark$ & \\
\hline & \multirow{4}{*}{$\begin{array}{l}\text { What are the } \\
\text { positive and } \\
\text { negative } \\
\text { experiences When I } \\
\text { practice teaching } \\
\text { activities? Why? }\end{array}$} & ÖA-4 & $\checkmark$ & & & & $\checkmark$ & & & $\checkmark$ & \\
\hline & & ÖA-12 & $\checkmark$ & & & & $\checkmark$ & & & & $\checkmark$ \\
\hline & & ÖA-24 & $\checkmark$ & & & & $\checkmark$ & & & & $\checkmark$ \\
\hline & & ÖA-30 & $\checkmark$ & & & & & $\checkmark$ & & & $\checkmark$ \\
\hline & \multirow{4}{*}{$\begin{array}{l}\text { If I had an } \\
\text { opportunity to apply } \\
\text { it what I would have } \\
\text { been done in the } \\
\text { class? Why? }\end{array}$} & ÖA-4 & $\checkmark$ & & & & & $\checkmark$ & & $\checkmark$ & \\
\hline & & ÖA-12 & $\checkmark$ & & & & & $\checkmark$ & & & $\checkmark$ \\
\hline & & ÖA-24 & $\checkmark$ & & & & $\checkmark$ & & & & $\checkmark$ \\
\hline & & ÖA-30 & $\checkmark$ & & & & & $\checkmark$ & & & $\checkmark$ \\
\hline
\end{tabular}


When the answers given by the pre-service teachers related to the questions about teaching materials towards the first practices are examined, it is seen that they predominantly are concentrated on whether teaching materials are effective or not. It is well determined that all of the pre-service teachers own reflection level in technical space in their first practices. As an example given to the reflection in technical space is the statement of the pre-service teacher with ÖA-12 code: "I tried to pick up the most appropriate materials in terms of my subject. I think that they are effective." The pre-service teacher mentioned that the materials he used were effective but he failed to mention what were these materials and in what point they were effective. The pre-service teacher was away from giving profound information. In the second practices of the pre-service teachers it is seen that all of the pre-service teachers except for the one with ÖA-12 code own reflection level in practice space. The pre-service teacher with ÖA-12 code owns the reflection level in technical space. As an example of reflection level in practice space the pre-service teacher with ÖA-24 code explained the following: "There was only one material I used. But it was not effective. For this reason, I think that there is a problem in understanding of the students. It would be more helpful for their understanding If I had drawn the material on a larger cardboard or visualized the subject." The pre-service teacher who made reflection in practice space did not mention only that materials were not effective. On the other hand, he analyzed the student behaviors in order to find out why the materials were not effective. In the third practice the pre-service teachers gave appropriate answers according to the reflection level in practice except for the one with ÖA-4 code. In the pre-service teacher with ÖA-4 code reflection level in the critical space is determined. He mentioned his views as follow: "I prepared a slide with the pictures and words related to the subject in order to be clearly under stable. That was effective. Because I tried to provide memorability by the pictures. By the words I provided perceptual discernibility by specifying the important things with dark colors. For my part, perception form of the learning material effects learning. The lasting learning can be maintained by making the subject to be learned discernable in different subjects. On the other hand, it would have been more effective if I used more materials. Because material provides effective and lasting learning. That is to say memorability would be more effective. For my part, though material is used for the purpose of supporting learning in some places it can be helpful for a more effective teaching by directly transferring content to student by assuming teacher role." When the reflection level in critical level of the pre-service science teacher with ÖA-4 code is examined it is well seen that he deals with the educational value of the teaching materials and develops original thoughts in relation with teaching materials. Similar findings obtained from the study of Tican [36]. In the study made by Tican [36] it is specified that teaching activities based on reflective thinking have positive effects in terms of reflective thinking and critical thinking.

Pre-service teachers were asked questions about positive and negative experiences they lived and is determined that they predominantly concentrated the points of accordance of practices with the plan, active participation of the students, using the material in time. All of the pre-service teachers made expressions about reflection in technical space towards first practice. The pre-service teachers failed to express sufficiently the reasons of negative and positive situations they experienced when the teaching activities are practiced. The expressions of the pre-service teachers were generally simplistic and superficial. As an example of this the pre-service teacher with ÖA-4 code said: "Telling the subject speedily and getting excited on the board were the negative situations. However, method and activities I used were appropriate in terms of the subject." In the second practices reflection level in the practice space was revealed except for the one with ÖA-30 code. Reflection level in critical space was revealed in the pre-service teacher with ÖA-30 code. The pre-service teachers who are making reflection in practice space not only describe the problems they experienced when they are applying the activities but they also expressed the reasons of the problems they experienced and what things should be done in removing the problems. The statements of the pre-service teacher with ÖA-24 code can be given as an example in this situation: "Station method was not effective. I do not think that this method is effective to provide lasting learnings. Because students do that activity without paying regard to it. Only we see that some students have talents about drawing nice pictures and versifying nice poems. I would have used jigsaw method instead of that. It would have been more lasting learnings and an effective group activity with excessive student participation." The pre-service teachers except for the one with ÖA-4 code make answers appropriate for reflection level in critical space. It is revealed reflection level in practice space in the pre-service teacher with ÖA-4 code. As an example of reflection level in critical space the pre-service teacher with ÖA-12 code made a statement as follow: "I had a positive experience while I applied the learning activities, because students in the class participated actively. My activities had become more efficient. There is a problem if a student does not participate in class or the questions are left without answers. Because there must be a reason of the silence and callousness in the class. In this case teaching will not be effective. Therefore, teacher has to interrogate himself or herself in terms of attitude he or she takes." When the statements made by the pre-service teachers who made reflections in critical space are examined it is well seen that they deal with the educational value of the practices in teaching process and develop original ideas. Similar findings are found in the study made by Bataineh, Karasnah, Barakat and Bataineh [35]. In the study that is made by Bataineh, Karasnah, Barakat and Bataineh [35] it is 
revealed that using reflective diary make the pre-service teachers active in learning of teaching.

When the reflections of the pre-service teachers who answered the questions towards what they should pay regard to when they practice teaching-learning activities are examined it is well seen that they predominantly concentrate on the pints such as raising materials, making similar practices, giving more examples related with the subject, using drama method. All of the pre-service teachers gave answers in the first practice in the level of reflection in technical space. The pre-service teachers make statements about what they would do when they make their practice again but did not mention sufficiently why they would make these practices again. As an example of this case the pre-service teacher with ÖA-24 said as follow: "If I practice once again I will extend the subject anymore and I will tell it slowly." In the second practice the pre-service teachers made statements appropriate to the reflection level. Only the pre-service teacher with ÖA- 24 code made a reflection in technical space. The pre-service teachers who make reflections in practice space, made statements not only definitive expressions for making students more active and providing alternative methods for effective learning but they also made detailed analysis in order to find out what they will do differently by setting out from the definitive statements. In the second practice the pre-service teachers made statements appropriate to the reflection level. Only the pre-service teacher with ÖA-24 code made a reflection in technical space. The pre-service teachers who make reflections in practice space made statements not only definitive expressions for making students more active and providing alternative methods for effective learning but they also made detailed analysis in order to find out what they will do differently by setting out from the definitive statements. As an example for the reflection in the practice space the pre-service teacher with ÖA-4 code said: "I could have made interpretation after drama but I did not consider it necessary as I have told the subject. However, it would have been more effective if I took several interpretations and I made an explanation. If I were a teacher, I would have asked the student to bring the tests after a week. I would have asked them to make a report about the test. I took the environment subject extensively because I simply made a pass. I could not attain the target. Because I could not make the point. At the same time, it would have been better if I could have made the test in a laboratory surrounding. Groups would interact with each other easily. Tests that made in class surrounding are not effective".

In the third practices the pre-service teachers except for the one with ÖA-4 code made reflections in the critical space. In the pre-service teacher with ÖA-4 code it is revealed reflection level in the practice space. When the statements of the pre-service teachers who made reflections in the critical space are examined it is seen that they deal with the educational values of the methods to be used when the practice is made once again and they made original inferences. The pre-service teacher with ÖA-30 code said the following about reflection in critical space: "If I had the chance to make a practice once again I would have used drama method. For my part, this is an appropriate method about meteorology subject. Because advantage of the drama method is to clear up everything and everything will be understandable. Drama should be used in every subject. In drama method individuals who develop empathy in social relations can be successful. For this reason, tasks should be assigned to the students who have talents in this regard. Otherwise, we may aggrieve students". Similar findings can be found in the study of Kozan [15]. In the study that is made by the Kozan [15] it is seen that spaces in the students' diaries, on which they made reflections by the practices developing reflective thinking skill, is changed towards end of the practice.

\subsection{Findings Obtained from the Reflective Diaries of the Pre-service Teachers on the Assessment of Teaching Process}

The findings that are revealed from analyzing the reflective diaries of the pre-service teachers on the assessment of teaching process are as follow. The findings are discussed by paying regard to the related literature.

When the findings obtained from the reflective diaries of the pre-service teachers towards the methods used in evaluation of teaching process are examined it is seen that assessment methods of all of the pre-service teachers are effective. As it is seen in Table 4, in all the pre-service teachers' reflection in technical space are revealed in technical space. The pre-service woman teacher with ÖA-4 code used a simple statement such as "the assessment and evaluation methods were effective" in relation with the reflection level in technical space. All of the pre-service teachers used statements in accordance with reflection level in practice space in the second practices. The pre-service teachers who made reflections in practice space mentioned that assessment and evaluation were effective. On the other hand, the pre-service teachers made interpretations about the sides where the assessment and evaluation methods they used to be effective based on individual perceptions. As an example of reflection level in practice space the pre-service teacher with ÖA-12 code said: "I have designed structured grid and true-false questions in today's class. I have applied the both assessments in a way I determined in my plan. The assessment and evaluation methods I used were effective. Because there were a symbolical reinforce that I used, a factor making students willing to give answers and increasing participation. I tried to recognize all of the students. I included all of the students into the assessment process. I intend to use this kind of reinforces in my teaching career. Because the reinforces make students focus on the activities in the best way." In the third practice of the pre-service teachers it is seen that reflection in the practice space is revealed in all the pre-service teachers except for the one with ÖA-4 code. When the answers of the 
pre-service teachers who made reflections in the critical space are examined it is seen that they deal with the educational value of the practices for which assessment is made and they made original inferences in relation with the assessment methods. The answer of the pre-service teacher with ÖA-24 code: "I have made assessment and evaluation by group activities. But I failed to tell the students what they made wrong as I was not able to use it effectively and I could not adjust the time. I could not tell the students what they did wrong. For this reason, they should be supplied with the indications signifying what they have done in mistake when they are given feedbacks. The exam questions should be discussed and explanations should be made for the students to achieve a more effective learning." can be given as an example. It can be said that the reflective diaries that are providing opportunities to the pre-service teachers to make analysis on the experiences they obtained from their own practices impact their interrogative statements
[14].

All of the pre-service teachers who gave answers to the questions on consistency between assessment methods which are used in practice and the targets of the subject specified that the assessment methods are consistent with the goals of the subject. All of the pre-service teachers made reflections in technical space in their practices. However, it is seen that the pre-service teachers who made reflections in technical space could not explain in which points and in what terms the assessment and evaluation methods are consistent with the goals they determined in relation with the subject. The pre-service teacher with ÖA-30 code made statements towards the reflection in technical space in such way "I have determined assessment and evaluation methods according to my acquisitions. That is why they were consistent." In the second practice all of the pre-service teachers except for the one with ÖA-24 code made statements on the reflection level in critical space.

Table 4. The findings obtained from the diaries of the pre-service teachers on assessment of teaching process

\begin{tabular}{|c|c|c|c|c|c|c|c|c|c|c|c|}
\hline \multirow{2}{*}{$\begin{array}{l}\text { Teaching } \\
\text { Process }\end{array}$} & \multirow[t]{2}{*}{ Questions } & \multirow{2}{*}{$\begin{array}{c}\text { Pre-service } \\
\text { Teacher }\end{array}$} & \multicolumn{3}{|c|}{$\begin{array}{l}\text { Reflection levels } \\
\text { (I. Practice) }\end{array}$} & \multicolumn{3}{|c|}{$\begin{array}{c}\text { Reflection levels } \\
\text { (II. Practice) }\end{array}$} & \multicolumn{3}{|c|}{$\begin{array}{l}\text { Reflection levels } \\
\text { (III. Practice) }\end{array}$} \\
\hline & & & $\mathrm{T}$ & $\mathrm{U}$ & $\mathrm{E}$ & $\mathrm{T}$ & $\mathrm{U}$ & $\mathrm{E}$ & $\mathrm{T}$ & $\mathrm{U}$ & $\mathrm{E}$ \\
\hline \multirow{14}{*}{ Assessment } & \multirow{3}{*}{$\begin{array}{l}\text { Are the assessment and } \\
\text { evaluation methods I } \\
\text { used } \\
\text { effective?(Why?/If not, } \\
\text { which methods can be } \\
\text { more effective?/Why? }\end{array}$} & ÖA-4 & $\checkmark$ & & & & $\checkmark$ & & & $\checkmark$ & \\
\hline & & ÖA-12 & $\checkmark$ & & & & $\checkmark$ & & & & $\checkmark$ \\
\hline & & ÖA-24 & $\checkmark$ & & & & $\checkmark$ & & & & $\checkmark$ \\
\hline & \multirow{4}{*}{$\begin{array}{l}\text { Are the assessment and } \\
\text { evaluation methods I } \\
\text { used consistent with } \\
\text { my targets?/Why?/If } \\
\text { not, why they are not } \\
\text { consistent?/Why? }\end{array}$} & ÖA-4 & $\checkmark$ & & & $\checkmark$ & & & & & $\checkmark$ \\
\hline & & ÖA-12 & $\checkmark$ & & & & & & & $\checkmark$ & \\
\hline & & ÖA-24 & $\checkmark$ & & & $\checkmark$ & $\checkmark$ & & & & $\checkmark$ \\
\hline & & ÖA-30 & $\checkmark$ & & & $\checkmark$ & & & & & $\checkmark$ \\
\hline & \multirow{3}{*}{$\begin{array}{l}\text { Whet are the negative } \\
\text { and positive } \\
\text { experiences I had in } \\
\text { assessment process? }\end{array}$} & ÖA-12 & $\checkmark$ & & & & $\checkmark$ & & & $\checkmark$ & \\
\hline & & ÖA-24 & $\checkmark$ & & & & $\checkmark$ & & & & $\checkmark$ \\
\hline & & ÖA-30 & $\checkmark$ & & & & $\checkmark$ & & & & $\checkmark$ \\
\hline & \multirow{4}{*}{$\begin{array}{l}\text { If I had chance for } \\
\text { practice once more } \\
\text { again what I would } \\
\text { have done different } \\
\text { things in assessment } \\
\text { process?/Why? }\end{array}$} & ÖA-4 & $\checkmark$ & & & & $\checkmark$ & & & $\checkmark$ & \\
\hline & & ÖA-12 & $\checkmark$ & & & & $\checkmark$ & & & & $\checkmark$ \\
\hline & & ÖA-24 & $\checkmark$ & & & & $\checkmark$ & & & $\checkmark$ & \\
\hline & & ÖA-30 & $\checkmark$ & & & & $\checkmark$ & & & $\checkmark$ & \\
\hline
\end{tabular}


When the statements made by the pre-service teachers who made reflections in the practice space are examined it is found that they failed to explain sufficiently the relations between assessment and evaluation methods and the targets of the subject. As an example, we can give the statement of the pre-service teacher with ÖA-4 code: I believe that I am consistent as I posed questions towards my targets. I questioned my assessment always in the frame of the subjects I told. For this reason, I think that the assessments I made are consistent with the targets, because I did not go out of the subject." In the third practice of the pre-service teachers' reflection in the critical space is revealed except the one with ÖA-12 code. When the statements made by the pre-service teachers who made reflection in the critical space are examined they developed original ideas in relation with the consistency between assessment methods and targets. The statement made by the pre-service teacher with ÖA-30 code can be given as an example: "My targets were the classification of elements as metal, a metal and inert-gas. In assessment and evaluation process it is aimed to find out the differentiations of the characteristics of metal, a metal and inert-gas. I was consistent in my targets. The assessment and evaluation process must be consistent with the targets. If the questions posed are not towards the targets they are not considered as valid. For this reason, targets have to be consistent with both subject integrity and with the assessment and evaluation." In this case it can be said that reflective diaries that providing opportunity to the pre-service teachers to think profoundly on their experiences play an important role [34]. The pre-service teachers were asked about positive and negative experiences they attained in the assessment process. They predominantly mentioned the points that assessments should made in accordance with plan and efficiency of assessment methods that are made by groups. All of the pre-service teachers made reflections in technical space in their first practices. The pre-service teachers who made reflections in technical spaces mentioned the positive and negative experiences they had in assessment process but they did not express the reasons of this situation. The statement of the pre-service teacher with ÖA-12 code can be given as an example: "I have not negative experience in the section of assessment. As my subject is short I have made a lot activity in short time." All of the teachers gave answers towards the reflection level in practice space in their second practice. The pre-service teachers who made reflections in practice space did not only positive and negative situations in the assessment process but they also explained the reasons of the mentioned situations and what should be done to solve the problems. The pre-service teacher with ÖA-30 said in this regard: "The only negative thing that I experienced in the assessment process was the structured grid method I had already prepared. Because the statements in this method were the examples given from daily life. I did not mention this point when I told the subject. For this reason, students had difficulties to give answers to these questions. The positive side was that I used symbolical reinforces for the assessment of the questions. This made the students more active in the class. Participation of the students increased. I intend to use such reinforces in my teaching career. In my practice I saw they motivated the students who are withdrawn and not willing to participate in the class." The pre-service teachers developed reflections in practice and critical spaces. The pre-service teacher ÖA-24 said: "The positive experience I had was the well-functioning of the groups with each other and that the subject was well understood in my assessment by matchup. On the other hand, the class answered to some questions that were given falsely. It must pay regard to the assessment. The questions may be confused or they may be answered by misunderstanding. For this reason, questions must be arranged carefully in the assessment. They have to be adjusted in such a way that they would not neither very easy nor very difficult. I had a negative experience in the assessment that the students became hesitant in some questions. There was some confusion in the characteristics of metal, a metal and semi metals. However, later the mistakes have been corrected. The latest assessment has been made with group. But generally every group gave right answers. In the end equality has been broken and I could give award. However, a question remained unanswered. I thought that equality would be provided again. There might be some negatives in the assessment but the important thing is to be able to eliminate these negative situations. A suggestion about solution has to be developed in order not to confuse the students." When the statements of pre-service teachers who made reflections in the critical space are examined it is seen that they developed original ideas about negative and positive situations that are seen in teaching-learning process and made inferences in this regard. Similar findings are seen in the study made by Langer [33]. In the study made by Langer [33] it has been found out that in developing reflection skills of the college students the learning diaries are effective.

The pre-service teachers were asked on which points they would pay regard to if the practicing assessment process had been repeated. The pre-service teachers gave predominantly answers like the number of questions has to be increase, similar practices should be done, more feedbacks have to be given, and more time has to be given. All of the pre-service teachers gave answers in accordance with the reflection level in the technical space in their first practice. The pre-service teacher with ÖA-12 code gave a superficial answer to the reflection in technical space as: "I would have made the same practice once more." The statements of the pre-service teachers for evaluation of teaching-learning process were typically simple and superficial. All of the pre-service teachers gave answers for the reflection in practice space in their second practices. The pre-service teachers who made reflection in practice 
space used not only definitive statements but they also made interpretations based on subjective perceptions towards the practices to be made in the assessment process. The answer of the pre-service teacher with ÖA-24 can be given as an example for this point: "If I had a chance to practice again I would have made more explanations in regard with the misunderstood questions and told them. Students may not correct these misunderstood questions. For this reason, an effective and full learning is out of question for the students. I would have paid them and ensured there would not be left any question mark in the minds of the students." In the third practices of the pre-service teachers it is seen that reflection in critical space is revealed except for one with ÖA-12 code. In the teacher with ÖA-12 code reflection level in practice level is revealed. This can be exemplified in his following answer: "I have never used a method except for the methods I realized in the assessment process. Because I picked up the appropriate methods which are able to assess and evaluate the behaviors that are necessary to be formed. The richness in assessment and evaluation methods makes it easy to be observability. Because increasing the number and type of the questions raising the correct answers of the students. If we measure up with limited number numbers or single type questions we will not realize the assessment completely." When the statements of the pre-service teachers who made reflections in critical space are examined it is seen that the pre-service teachers mostly dealt with the educational values towards the activities in regard with assessment of teaching process and made original inferences. This finding shows parallelism with the findings in the study of Erginel [13] and Gencer [14]. The methods that developing reflective thinking such as reflective diary and video analysis in the both study explains that they give opportunities to the pre-service teachers to make reflective analysis on their own practices.

\section{Conclusions and Suggestions}

The goal of this study is to improve reflective thinking skills of the pre-service teachers during the training period. The results that are obtained from the discussions on collected data are as follow. The practices intended for improving reflective thinking and comprising reflective diary, micro teaching, feedback and guidance for a period of eight weeks have been effective on improving reflective thinking levels of pre-service teachers.

Keeping reflective diary regularly which is one of the activities intended for improving reflective thinking skills has been effective on developing reflective thinking. On the other hand, using reflective diaries together with micro training contributed to improving of thinking skills of the pre-service teachers. The effective feedbacks and discussions that realized between instructors and the pre-service teachers as well as the effective communication have been effective on the reflective thinking. On the other hand, keeping reflective diaries has been effective on the pre-service teachers in terms of understanding the deficiencies and problems they had. The reflective diary created awareness in the pre-service teachers about removing deficiencies. The reflective diaries encouraged the pre-service teachers to make efforts to realize what have to be done. The responsibility assumed by the pre-service teachers in regard with the reaching skills means that they own high level reflective thinking skill. On the other hand, giving feedbacks by the instructor in regard with the reflections of the pre-service teachers in reflective thinking level made improvement on the reflective thinking levels of the pre-service teachers. On the other hand, using micro training and reflective diaries together as if they are supplementary for each other has been effective on the reflective thinking skills of the pre-service teachers.

In this study that is made to improve reflective thinking skills of the pre-service teachers in the course of teaching process following suggestions are made based on the results:

- The pre-service teachers have to acquire further experiences in the points of teaching methods they use when they are watching the videotapes showing their own class practices, teaching materials, evaluation methods, interactions with the students and the effects on the students. Reflective diaries are the effective way on using their own reflective thinking skills on these experiences. In this way the pre-service teachers may use the reflective skills they acquired for effective presenting surroundings in their teaching lives.

- Reflective diary, micro teaching, video tapes, interviews and feedbacks may be effective on improving reflective thinking skills. They have to be started up in the earliest period of the teaching education and be used as long as possible.

- The pre-service teachers have to make applied studies in terms of both theoretically and micro teaching and to keep diaries for their own improvements.

- Experiences have to be transformed into knowledge, problems have to be dealt systematically and studies have to be carried out to equip the pre-service teachers with diary keeping skills.

- Instructors have to make studies together with the students or researches for keeping reflective diaries.

\section{REFERENCES}

[1] Ersözlü, Z. N. (2008). Yansıtıcı düşünmeyi geliştirici etkinliklerin ilköğretim 5. sınıf öğrencilerinin sosyal bilgiler dersindeki akademik basarılarına ve tutumlarına etkisi. Yayınlanmamıs doktora tezi, Frrat Üniversitesi Sosyal Bilimler Enstitüsü, Elazı̆̆.

[2] Demirören, M., Koşan, A. M. A. ve Palaoğlu, Ö. (2009). Bir öğrenme ve değerlendirme yöntemi olarak "portfolyo". Ankara Üniversitesi Tıp Fakültesi Mecmuas1, 62 (1), 19-24. 
[3] Pollard, A. (2005). Reflective teaching: evidence-informed professional practice. New York: Continuum.

[4] Dolapçıoğlu, S. D. (2007). Sınıf öğretmenlerinin yansıtıcı düşünme düzeylerinin değerlendirilmesi. Yayınlanmamış yüksek lisans tezi, Mustafa Kemal Üniversitesi Sosyal Bilimler Enstitüsü, Hatay.

[5] Korathagen, F. and Wubbes, T. (2008). Characteristics of reflective teachers education. Korathagen, F. (Ed.), Linking practice and theory: the pedagogy of realistic teacher education, New Jersey: Lawrance Erlbaum, 133-144.

[6] Stevens, D. D. and Cooper, J. E. (2009). Journal keeping: how to use reflective journals for effective teaching and learning professional insight and positive change. Virginia: Stylus Publishing.

[7] Barak, L., O. and Yinon, H. (2007). When theory meets practice: what student teachers learn from guided reflection on their own classroom discourse. Teaching and Teacher Education, 23, 957-969.

[8] Harford, J. and MacRuairc, G. (2008). Engaging student teachers in meaningful reflective practice. Teaching and Teacher Education, 24 (7), 1884-1892.

[9] Yeşilbursa, A. (2011). Reflection at the interface of theory and practice: An analysis of pre-service English language teachers' written reflections. Australian Journal of Teacher Education, $36,104-116$

[10] Kellum, K. E. H. (2009). Structured reflectıng teams in group supervision: a qualitative study with school counseling interns. Unpublished doctoral dissertation, Graduate College of The University of Iowa, Iowa.

[11] Yenilmez, K. ve Yolcu, B. (2007). Öğretmen Davranışlarının Yaratıcı Düşünme Becerilerinin Gelişimine Katkısı. Sosyal Bilimler Dergisi, (18).

[12] Van Manen, M. (1977). Linking ways of knowing with ways of being practical. Curriculum Inquiry, 6 (3), 205-228.

[13] Erginel, S. Ş. (2006). Developing reflective teachers: a study on perception and improvement of reflection in pre-service teacher education. Orta Doğu Teknik Üniversitesi Sosyal Bilimler Enstitüsü, Yayınlanmamıș doktora tezi, Ankara.

[14] Gencer, A. S. (2008). Professional development of pre-service biology teachers through reflective thinking. Yayınlanmamış doktora tezi, Orta Doğu Teknik Üniversitesi Orta Öğretim Fen ve Matematik Alanları Eğitimi Bölümü, Ankara.

[15] Kozan, S. (2007). Yansitıcı düşünme becerisinin kaynak tarama ve rapor yazma derslerindeki etkisi. Yüksek lisans tezi, Selçuk Üniversitesi, Sosyal Bilimler Enstitüsü, Konya.

[16] Şahin, Ç. (2009). Fen bilgisi öğretmen adaylarının yansıtıcı düşünme yeteneklerine göre günlüklerinin incelenmesi. Hacettepe Üniversitesi Eğitim Fakültesi Dergisi, 36, 225-236.

[17] Taggart, G. L. and Wilson, A. P. (2005). Promoting reflective thinking in teachers: 50 action strategies. California: Corwin Press.

[18] Töman, U. ve Çimer, O. S. (2014a). Investıgatıon by skılls of pre-service science teachers' reflectıve thınkıng from journals. Journal of Computer and Education Research (JCER), 2 (4), 166-190.
[19] Ünver, G. (2010). Yansitıcı düşünme. Eğitimde yeni yönelimler. Özcan Demirel (Ed.), Ankara: Pegem Akademi.

[20] Dervent, F. (2012). Yansitıcı düşünmenin beden eğitimi öğretmen adaylarının mesleki uygulamalarına etkisi. Yayınlanmamış doktora tezi, Marmara Üniversitesi, Eğitim Bilimleri Enstitüsü, İstanbul.

[21] Wilson, J. and Jan, W. L. (1993). Thinking for themselves developing strategies for reflective learning. Australia: Eleanor Curtain Publishing.

[22] Mills, G. E. (2003). Action research a guide for the teacher researher (Second Ed.). New Jersey: Pearson Education, Inc.

[23] McMillan, J. H. (2004). Educational research: fundematals for the consumer. (Fourth Ed.). USA: Pearson Education.

[24] Yıldırım, A. ve Şimşek, H. (2011). Nitel araştırma yöntemleri. Ankara: Seçkin Yayınevi.

[25] Şencan, H. (2005). Sosyal ve davranışsal ölçümlerde güvenilirlik ve geçerlilik. Ankara: Seçkin Yayıncılık.

[26] Ay, S. T. (2010). Sosyal bilgiler dersinde yerel toplum çalışmalarından yararlanma: bir eylem araştırması. Yayınlanmamış doktora tezi, Anadolu Üniversitesi, Eğitim Bilimleri Enstitüsü, Eskişehir.

[27] Kuzu, A. (2005). Oluşturmacılığa dayalı çevrimiçi destekli öğretim: bir eylem araştırması. Yayımlanmamış doktora tezi. Eskişehir: Anadolu Üniversitesi Eğitim Bilimleri Enstitüsü.

[28] Miller, M. A. (2007). Differentiated reading instruction and classroom management structures that promote reading development. Yayınlanmamış doktora tezi. University of Florida.

[29] Ekiz, D. (2006). Self-observationand peer observation: reflective diaries of primary student- teachers. Elementary Education Online, 5 (1), 47-57.

[30] Köksal, N. ve Demirel, Ö. (2008). Yansıtıcı düşünmenin öğretmen adaylarının öğretmenlik uygulamalarına katkıları. Hacettepe Üniversitesi Eğitim Fakültesi Dergisi, 34, 189-203.

[31] Yorulmaz, M. (2006). İlköğretim I. kademesinde görev yapan sınıf öğretmenlerinin yansıtıcı düşünmeye ilişkin görüş ve önerileri (Diyarbakır İli Örneği). Yayınlanmamış yüksek lisans tezi, Frrat Üniversitesi, Elazığ.

[32] Punch, F.K. (2005). Sosyal araştırmalara giriş nitel ve nicel yaklaşımlar. Ankara: Siyasal Kitabevi.

[33] Langer, A. M. (2002). Reflecting on practice: using learning journals in higher and continuing education. Teaching in Higher Education, 7 (3), 337-351.

[34] Norton, J. L. (1994). Creative thinking and reflective practitioner. Journal of Instructional Psychology. 21 (2) 139-148.

[35] Bataineh ,R. F., El Karasneh ,M.S., Barakat ,A. A. and Bataineh, R. F. (2007). Jordanian pre-service teachers' perceptions of the portfolio as a reflective learning tool. Asia-Pacific Journal of Teacher Education, 35 (4), 435-454.

[36] Tican, C. (2013). Yansıtıcı düşünmeye dayalı etkinliklerin öğretmen adaylarının yansıtıcı düşünme becerilerine, eleştirel düşünme becerilerine, demokratik tutumlarına ve akademik başarılarına etkisi. Yayınlanmamış doktora tezi, Gazi Üniversitesi, Ankara. 
[37] Valli, L. (1992). Reflective teacher education: cases and critiques. Albany: State University of New York Press.
[38] Evans, L. (2009). Reflective Assessment and Student Achievement in High School English, Unpublished doctoral dissertation, Seattle Pacific University, Seattle. 